or as a weak electrolyte. It seems probable, however, that even the pure hydride if it could be obtained in the molten state would prove to be an excellent conductor of electricity.

\title{
Summary
}

A new method was worked out for the preparation of pure sodium and potassium hydrides. They were obtained in the form of beautiful white, needle-like crystals. Potassium hydride decomposes with explosive violence in moist air.

Calcium hydride was prepared free from metallic calcium.

The eutectic mixture of potassium and lithium chlorides was found to be a solvent for hydrides.

A solution of calcium hydride in this eutectic mixture was electrolyzed, and hydrogen was given off at the anode in the quantity required by Faraday's law. No gas was liberated at the cathode.

The writer wishes to acknowledge his appreciation of the many helpful suggestions of members of the Faculty at the University of California where this investigation was made, and to thank Professor G. N. Lewis especially, at whose suggestion and under whose direction this research was prosecuted.

Berkeley, CALifornia

[CONTribution From the Chemical, Laboratory of the University of Michigan]

\section{BIMETALLIC ELECTRODE SYSTEMS IN ELECTROMETRIC ANALYSIS. I. SYSTEMS COMPRISING TWO DISSIMILAR METALS}

BY H. H. WILLARD AND FLORENCE FENWICK

Received September 11, 1922

\section{Introduction}

A large amount of investigation has been made during the past 10 years on the extension of the use of the electrometric indicator in volumetric analysis and the simplification of the apparatus required for potentiometric work. In connection with the latter, various changes have been suggested both for the measuring instruments employed ${ }^{1}$ and the electrode arrangement used. Kolthoff ${ }^{2}$ has classified the electrode systems used in electrometric analysis under the following three heads. (1) The system ordinarily used, consisting of an unattackable metal electrode and a constant half-cell, usually a calomel reference electrode. (2) The Pinkhof system, in which the calomel electrode is replaced by a compensation electrode

${ }^{1}$ Hildebrand, This Journal, 35, 869 (1913). Forbes and Bartlett, ibid., 35, 1527 (1913). Kelley and Conant, ibid., 38, 341 (1916). Kelley, Adams and Wiley, J. Ind. Eng. Chem., 9, 780 (1917). Roberts, This Journal, 41, 1358 (1919). Treadwell and Weiss, Helv. Chim. Acta, 2, 680 (1919). Goode, This Journal, 44, 26 (1922).

${ }^{2}$ Kolthoff, Chem. Weekblad, 50, 659 (1920). 
the potential of which is exactly equal to that of the unattackable electrodesolution at the completion of the titration. The end-point is marked by a reversal of polarity. The arrangement has a number of disadvantages. Every titration has its peculiar electrode system, there is no warning of the approach to the end-point, and it is difficult to compensate for the effects of concentration and foreign salts. (3) The Treadwell system. V. D. Treadwell uses, in place of a standard electrode, a half-cell which contains a solution of the same composition as the solution titrated at its end-point, in contact with a second unattackable electrode. The disadvantage here is the specific character of any one arrangement.

The idea of using bimetallic systems in electrometric analysis was suggested by Hostetter and Roberts ${ }^{3}$ in connection with the titration of iron in small quantities. Because of the practical absence of a break at the end-point in the titration of ferrous sulfate with $0.1 \mathrm{~N}$ potassium dichromate when palladium replaced the usual platinum electrode, Hostetter and Roberts called attention to the possibility of substituting a palladium electrode for the calomel reference electrode.

\section{Preliminary Investigation of Bimetallic Systems}

\section{Palladium}

Such a means of simplifying the usual apparatus seemed distinctly worth following up, so we attempted first to verify the results of these authors in the titration of solutions of higher iron content. Fig. 1 shows the results of the titration of $75 \mathrm{cc}$. of a solution of ferrous sulfate approximately 0.033 $N$ and containing a high concentration of hydrochloric acid. Curve 1 is the curve of the system, Pd-Titrated Soln.-0.1 $N$ $\mathrm{KCl}, \mathrm{HgCl}-\mathrm{Hg}$, and Curve 2 of the sys- 30 tem, Pt-Titrated Soln. $-0.1 \mathrm{~N} \mathrm{KCl}, \mathrm{HgCl}-$ $\mathrm{H} y$. The platinum electrode was a piece of pure platinum wire $46 \mathrm{~mm}$. long and $0.49 \mathrm{~mm}$. in diameter. The palladium electrode was a thin strip of foil about 5 $\mathrm{mm}$. wide and $10 \mathrm{~mm}$. long. The difference in behavior of the 2 metals at the end-point is obvious.

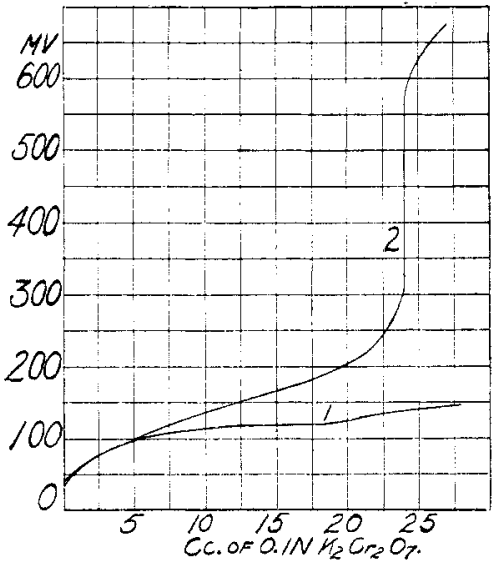

Fig. 1.

Upon substituting the palladium electrode for the calomel an extremely sharp but transient end-point was obtained. In order to investigate further the fleeting character of this end-point, the palladium and calome1 electrodes were connected in the circuit through a double-throw switch

${ }^{3}$ Hostetter and Roberts, This Journal, 41, 1343, footnote 1 (1919). 
so that at any point during the course of the titration the potential of the platinum electrode against both the calomel and palladium might be measured. The results are shown graphically in Fig. 2 . The solution contained $25.00 \mathrm{cc}$. of $0.1092 \mathrm{~N}$ ferrous sulfate and $50 \mathrm{cc}$. of hydrochloric acid, sp. gr. 1.18, in a total volume of 75 cc. Curve 1 is the Pt-Pd curve, Curve 2 is the Pt-calomel. The first sharply defined break came after the calculated end-point and the voltage fell almost instantaneously to its former value with both reference electrodes. The addition of $0.1 \mathrm{cc}$. portions of potassium dichromate caused a sharp rise

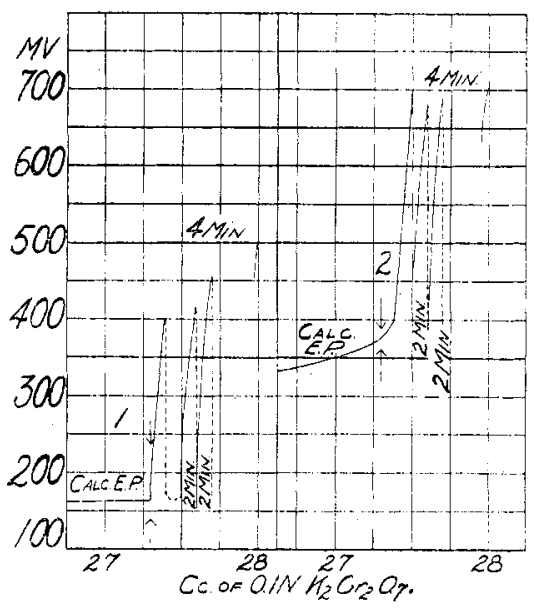

Fig. 2. followed by a slow falling of the potential until there was $0.7 \mathrm{cc}$. of dichromate in excess of the calculated amount. At this point there was no fall, but rather a slow rise for the observed space of 4 minutes. Since the end-point behavior was the same with both electrode systems it is apparent that variable voltage effects are not due to any property of the metallic palladium but the cause of the difficulty must lie in the solution itself. The fact that the first fleeting break occurred in the presence of a supposed excess of the oxidizing agent indicated that the titrated solution contained other reducing agents than the known amount of ferrous iron. This could mean only that the palladium electrode was attacked. To ver-

\section{TABLE I}

Titration of Ferrous Iron with Platinum-Palladium Electrodes

The solutions titrated contained $25.00 \mathrm{cc}$. of approximately $0.1 \mathrm{~N}$ ferrous sulfate in an initial volume of $75 \mathrm{cc}$. The oxidizing agent was $0.1 \mathrm{~N}$ potassium dichromate. The time required for the titration was 5 minutes except in the fifth experiment when it was 25 minutes

$\begin{array}{cccc}\begin{array}{c}\text { Length of } \\ \text { electrode }\end{array} & \begin{array}{c}\text { Acid } \\ \text { conc. }\end{array} & \begin{array}{c}\text { Error } \\ \mathrm{Nm}_{2} \mathrm{Cr}_{2} \mathrm{O}_{7}\end{array} & \begin{array}{c}\text { Character of } \\ \text { end-point }\end{array} \\ & \begin{array}{c}\mathrm{Cc} . \\ \mathrm{HCl}\end{array} & +0.30 & \text { Good } \\ & 66 & +0.30 & \text { Good } \\ 10 & 33 & +0.30 & \text { Good } \\ & 13 & +0.30 & \text { Poor } \\ & 4 & 1.00 & \text { Good } \\ 8 & 66 & & \text { Poor } \\ 4 & \text { Any Conc. } \mathrm{H}_{2} \mathrm{SO}_{4} & & \text { Good } \\ \text { Point } & 66 & +0.26 & \text { Fair } \\ & 66 & +0.12 & \text { None }\end{array}$

ify this conclusion, titrations were carried out to the first sharp break with solutions of different acid concentration and palladium electrodes 
of varying surface exposure, the other electrode being pure platinum. The results are recorded in Table I. In this, and all other tables, the concentration of acid in the solution is expressed as percentage by volume of sulfuric acid, sp. gr. 1.84, or of hydrochloric acid, sp. gr. 1.18.

Although the error was considerably reduced by decreasing the surface exposure of the palladium electrode and the time required for the titration, it was not found possible to reduce it to within acceptable limits. A mere point contact electrode gave no results and the use of a weakly acid solution of hydrochloric acid or sulfuric acid of any strength was unsatisfactory. Apparently the difference in voltage of the systems, $\mathrm{Pt}-\mathrm{FeSO}_{4}-\mathrm{Pd}$ and $\mathrm{Pt}-\mathrm{Fe}_{2}\left(\mathrm{SO}_{4}\right)_{3}-\mathrm{Pd}$, is insufficient for the appearance of a a sharp break, and it is only by virtue of the presence of some palladous ion that this occurs. At the same time, some reduction of the ferric salt occurs and an excess of the oxidizing agent must, therefore, be used.

In spite of the unsatisfactory results obtained with pure palladium it seemed possible that a dilution of the palladium in the electrode might decrease the error in the titration to a negligible amount for analytical purposes. Hostetter and Roberts ${ }^{3}$ found a very appreciable break with a gold electrode in the dichromate titration of ferrous sulfate but not nearly as good as with clean platinum. Alloys of gold and palladium of small surface exposure and containing variable proportions of the constituents were, therefore, tried, with the same platinum electrode used before. The results were irregular and much too high.

To complete the work with palladium, a platinum-palladium alloy was made and comparative titrations run using as reference electrodes with platinum pure palladium wire 1 $\mathrm{mm}$. in diameter, $7 \mathrm{~mm}$. long, and the alloy. The oxidizing agent was added as rapidly as possible and the electrodes were not in contact with the solution for more than 3 minutes during each titration. The palladium wire was a more compact form of the metal than the foil used previously and the error was very appreciably reduced. It seemed reasonable to conclude from these later results that under carefully regulated conditions palladium and platinum-palladium may be employed as electrodes

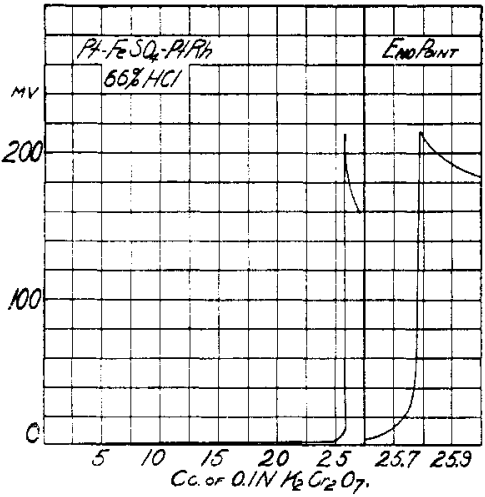

Fig. 3. with reasonable accuracy. Irregularities persisted, however, to a considerable extent. The palladium wire showed visible signs of attack after some 50 titrations. It seemed advisable, therefore, to investigate thoroughly other metals less easily attacked, especially those of the platinum group, 
with a view to finding a bimetallic system capable of giving more regular results.

\section{Platinum and Rhodium}

The first new combination tried was that of pure platinum with platinumrhodium thermocouple wire. Fig. 3 gives the titration curve of this system with potassium dichromate.

The results of a number of titrations are given in Table II. All solutions contained $25.00 \mathrm{cc}$. of approximately $0.1 \mathrm{~N}$ ferrous sulfate. The error in the case of the dichromate titrations is based on the electrometric standardization with platinum and silver chloride electrodes. ${ }^{4}$ The visual end-point standardization is used in the case of permanganate titrations.

There are some differences between the dichromate and the permanganate titrations, rather more in degree than in character, which will be brought out later. Fig. 5 is the curve of the permanganate titration in $20 \%$ sulfuric acid, using a platinum-platinum-rhodium system.

\section{Tungsten}

Because of its high resistance to acids, tungsten seemed to offer a promising electrode material. A piece of tungsten wire $2 \mathrm{~mm}$. in diameter was used as electrode in a number of titrations, the results of which are recorded in Table III. Twenty-five cc. of $0.1 \mathrm{~N} \mathrm{FeSO}_{4}$ was used in each case, as before.

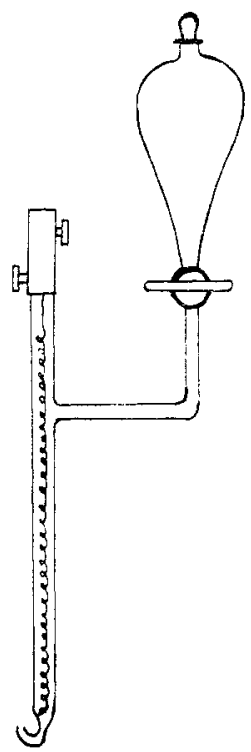

Fig. 4.

${ }^{4}$ For all titrations requiring a constant half-cell, the silver chloride electrode was found much superior to the calomel. Four electrodes were made up as described by MacInnes and Parker, THIs Journal, 37, 1449 (1915), except that a coil of silver wire replaced the platinum gauze used by these authors. The wire was plated with silver from a cyanide bath, coated with silver chloride by making it the anode in a solution of sodium chloride, and placed in $0.1 \mathrm{~N}$ potassium chloride in the container shown in Fig. 4.

The reservoir was a $20 \mathrm{cc}$. dropping funnel. The great advantage of this type of holder. is the comparatively negligible resistance offered by the short column of liquid intervening between the titrated solution and the metal of the electrode.

The potential of each of the electrodes made was measured against a $0.1 \mathrm{~N}$ calomel electrode and the difference found to be 0.045 volt in every case. Lewis, Brighton and Sebastian, THIS JoUrvat, 39, 2252 (1917), obtained the value 0.046 volt. Aiter several months of severe and continuous use the potential of one of the electrodes was again measured. There was no appreciable change. Although the silver chloride does not possess the high degree of reproducibility of the calomel, it is more rugged, comes more quickly to equilibrium, and the potential of single elements is more constant than with the latter. 
The curves in the region of the end-point for both dichromate and permanganate titrations with platinum and tungsten electrodes are shown

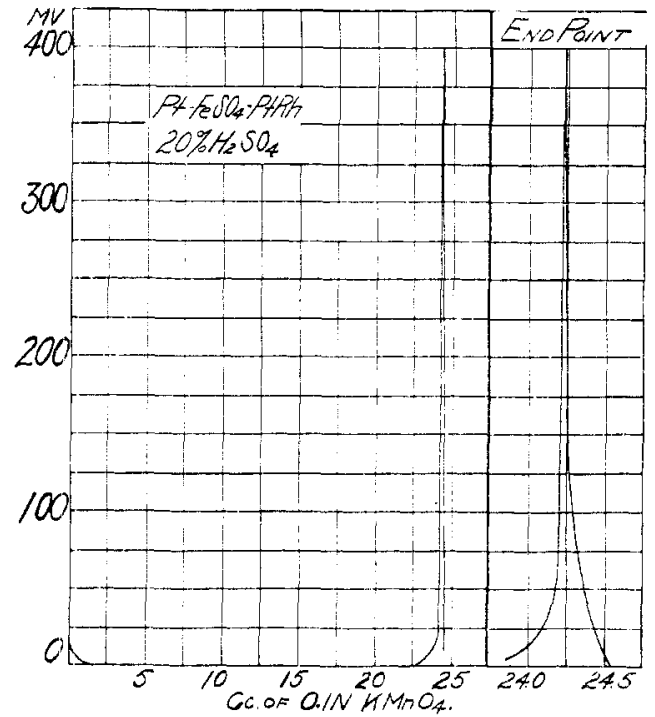

Fig. 5.

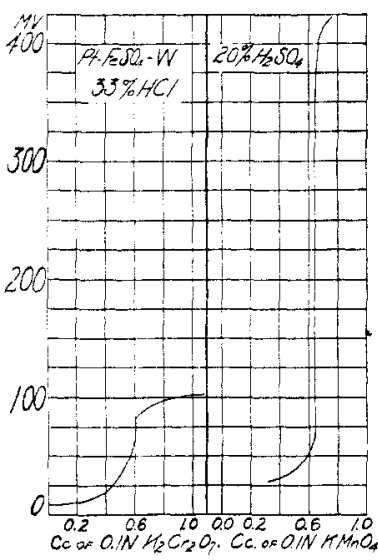

Fig. 6.

in Fig. 6. According to the above tabulation there is no determinable break with tungsten-silver-chloride combinations. This is clearly shown by Curve 1, Fig. 7 , which is the end-point curve for permanganate titrations of ferrous sulfate in $20 \%$ sulfuric acid and Curve 2 for dichromate titrations in $33 \%$ hydrochloric acid.

Quantitatively considered the results in Tables II and III are decidedly encouraging. In $66 \%$ hydrochloric acid too little oxidizing agent was required probably due to oxidation by the air. ${ }^{5}$ (See Table II.) With

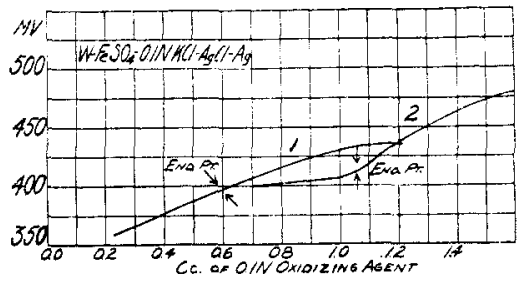

Fig. 7 . an acidity of $50 \%$ or less the results are very satisfactory. The permanganate titration of ferrous sulfate solutions containing free sulfuric acid gave results slightly below the visual end-point. The difference is quite small enough to be accounted for by the excess of the oxidizing agent required for the visual end-poinc. In hydrochloric acid solution the amount of permanganate required with the platinumplatinum-rhodium system is somewhat greater than in dil. sulfuric acid. This difference is not great, but since the palladium elec-

5 Eppley and Vosburgh, This Journal, 44, 2148 (1922), found the opposite effect using the reverse titration, in which oxidation by the air would not occur. 
trode was found to be very appreciably attacked under similar conditions, especially in the presence of an increased iron content, it seemed advisable to investigate further the error involved here. The iron content of the solutions was increased by the addition of a strong solution

TABLE II

Titration of Ferrous Iron with Electrodes of Platinum and Platinum-Rhodium

\begin{tabular}{|c|c|c|c|c|c|}
\hline \multirow[b]{2}{*}{$\begin{array}{l}\text { Electrode } \\
\text { system }\end{array}$} & \multirow{2}{*}{$\begin{array}{c}\text { Acidity } \\
\% \mathrm{HCl} \\
\text { by volume }\end{array}$} & \multicolumn{2}{|c|}{$0.1 N \mathrm{~K}_{2} \mathrm{Cr}_{2} \mathrm{O}_{7}$} & \multicolumn{2}{|c|}{$0.1 \mathrm{~N} \mathrm{KMnO}_{4}$} \\
\hline & & $\begin{array}{c}\text { Average } \\
\text { error } \\
\text { Cc. }\end{array}$ & $\begin{array}{c}\text { Average } \\
\text { break } \\
\text { Mv. }\end{array}$ & $\begin{array}{c}\text { Average } \\
\text { error } \\
\text { Cc. }\end{array}$ & $\begin{array}{c}\text { Average } \\
\text { break } \\
\text { Mv. }\end{array}$ \\
\hline \multirow[t]{8}{*}{ Pt-PtRh } & 66 & -0.12 & 104 & +0.18 & 20 \\
\hline & 50 & 0.00 & 97 & +0.08 & 49 \\
\hline & 33 & 0.00 & 48 & -0.05 & 40 \\
\hline & 20 & +0.01 & 32 & +0.01 & 29 \\
\hline & 13 & 0.00 & 47 & 0.00 & 69 \\
\hline & 6 & -0.02 & 26 & +0.06 & 38 \\
\hline & $26 \mathrm{H}_{2} \mathrm{SO}_{4}$ & 0.00 & 105 & & \\
\hline & $20 \mathrm{H}_{2} \mathrm{SO}_{4}$ & $\ldots$ & $\ldots$ & -0.03 & 334 \\
\hline \multirow[t]{3}{*}{$\mathrm{Pt}-\mathrm{AgCl}$} & 66 & $\ldots$ & $\ldots$ & -0.21 & 298 \\
\hline & 50 & $\ldots$ & $\ldots$ & +0.01 & 204 \\
\hline & 33 & $\ldots$ & $\ldots$ & 0.00 & 304 \\
\hline PtRh-AgCl & 33 & $\ldots$ & $\ldots$ & $\ldots$ & 237 \\
\hline
\end{tabular}

TABLE III

Titration of Ferrous Iron with Electrodes of Platinum, PlatinumRHODIUM AND TUNGSTEN

\begin{tabular}{|c|c|c|c|c|c|}
\hline \multirow{3}{*}{$\begin{array}{l}\text { Electrode } \\
\text { system }\end{array}$} & \multirow{3}{*}{$\begin{array}{l}\text { Acidity } \\
\% \text { Acid }\end{array}$} & \multicolumn{2}{|c|}{$0.1 N \mathrm{~K}_{2} \mathrm{Cr}_{2} \mathrm{O}_{7}$} & \multicolumn{2}{|c|}{$0.1 \mathrm{~N} \mathrm{KMnO}$} \\
\hline & & $\begin{array}{c}\text { Average } \\
\text { errot }\end{array}$ & $\begin{array}{c}\text { Average } \\
\text { break }\end{array}$ & $\begin{array}{l}\text { Average } \\
\text { error }^{a}\end{array}$ & $\begin{array}{c}\text { Average } \\
\text { break }\end{array}$ \\
\hline & & Cc. & Mv. & Ce. & Mv. \\
\hline \multirow{5}{*}{ Pt-W } & $50 \mathrm{HCl}$ & +0.02 & 31 & -0.04 & 76 \\
\hline & $33 \mathrm{HCl}$ & 0.00 & 34 & -0.05 & 176 \\
\hline & $20 \mathrm{HCl}$ & & . . & -0.05 & 100 \\
\hline & $20 \mathrm{H}_{2} \mathrm{SO}_{4}$ & & . & -0.04 & 252 \\
\hline & $13 \mathrm{H}_{2} \mathrm{SO}_{4}$ & -0.02 & 14 & -0.03 & 81 \\
\hline $\mathrm{W}-\mathrm{AgCl}$ & $\begin{array}{l}50 \mathrm{HCl} \\
20 \mathrm{H}_{2} \mathrm{SO}_{4}\end{array}$ & \multicolumn{2}{|c|}{ No end-point } & \multicolumn{2}{|c|}{ No end-point } \\
\hline PtRh-W & $33 \mathrm{HCl}$ & -0.01 & 72 & -0.02 & 320 \\
\hline & $20 \mathrm{H}_{2} \mathrm{SO}_{4}$ & -0.04 & 101 & -0.04 & 494 \\
\hline
\end{tabular}

of ferric chloride ( $1 \mathrm{cc} .=0.086 \mathrm{~g}$. of iron) in which the ferrous iron had been carefully determined electrometrically by titration with $0.01 \mathrm{~N}$ potassium dichromate and $0.001 \mathrm{~N}$ potassium permanganate solutions (29.07 cc. of ferric chloride $=2.50 \mathrm{~g}$. of iron and contained $0.36 \mathrm{cc} .0 .1 \mathrm{~N}$ ferrous iron). The results of a number of titrations are given in Table IV.

The error is brought well within allowable limits by the addition of manganous sulfate even in solutions high in iron. It is apparently due to a very slight decomposition of the hydrochloric acid, liberating chlorine. 
The results show that the electrometric method gives a means of titrating strong hydrochloric acid solutions of ferrous iron with permanganate.

TABLE IV

"Iitration of Ferrous Iron with Permanganate in Hydrochloric Acid

Solutions Containing Much Ferric Iron

In all cases the acid concentration was $33 \%$ by volume of hydrochloric acid, sp. gr. 1.18. The total iron was $0.14 \mathrm{~g}$. in the third experiment and $2.64 \mathrm{~g}$. in all others

\begin{tabular}{|c|c|c|c|}
\hline $\begin{array}{l}\text { Electrode } \\
\text { system }\end{array}$ & $\begin{array}{l}\mathrm{MnSO}_{4} \\
\text { (cryst.) } \\
\text { G. }\end{array}$ & $\begin{array}{c}\text { Average } \\
\text { break } \\
\text { Mv. }\end{array}$ & $\begin{array}{c}\text { Error in } \\
0.1 \mathrm{~N} \mathrm{KMnO} \\
\text { Cc. }\end{array}$ \\
\hline \multirow[t]{2}{*}{$\mathrm{Pt}-\mathrm{AgCl}$} & None & 186 & +0.03 \\
\hline & 5 & 172 & 0.00 \\
\hline \multirow[t]{3}{*}{ Pt-PtRh } & None & 27 & +0.02 \\
\hline & None & 17 & +0.07 \\
\hline & 5 & 46 & -0.02 \\
\hline \multirow[t]{2}{*}{$P t-W$} & None & 182 & +0.07 \\
\hline & 5 & 170 & +0.03 \\
\hline
\end{tabular}

\section{Summary of Preliminary Investigation}

A number of electrode combinations other than those already described were investigated. An attempt has been made to tabulate the main features of all the combinations in Table V. Unless otherwise specified the solutions titrated contained $25.00 \mathrm{cc}$. of an approximately $0.1 \mathrm{~N}$ ferrous sulfate solution in an initial volume of $75 \mathrm{cc}$, $20 \%$ by volume of conc sulfuric or $33 \%$ conc. hydrochloric acid.

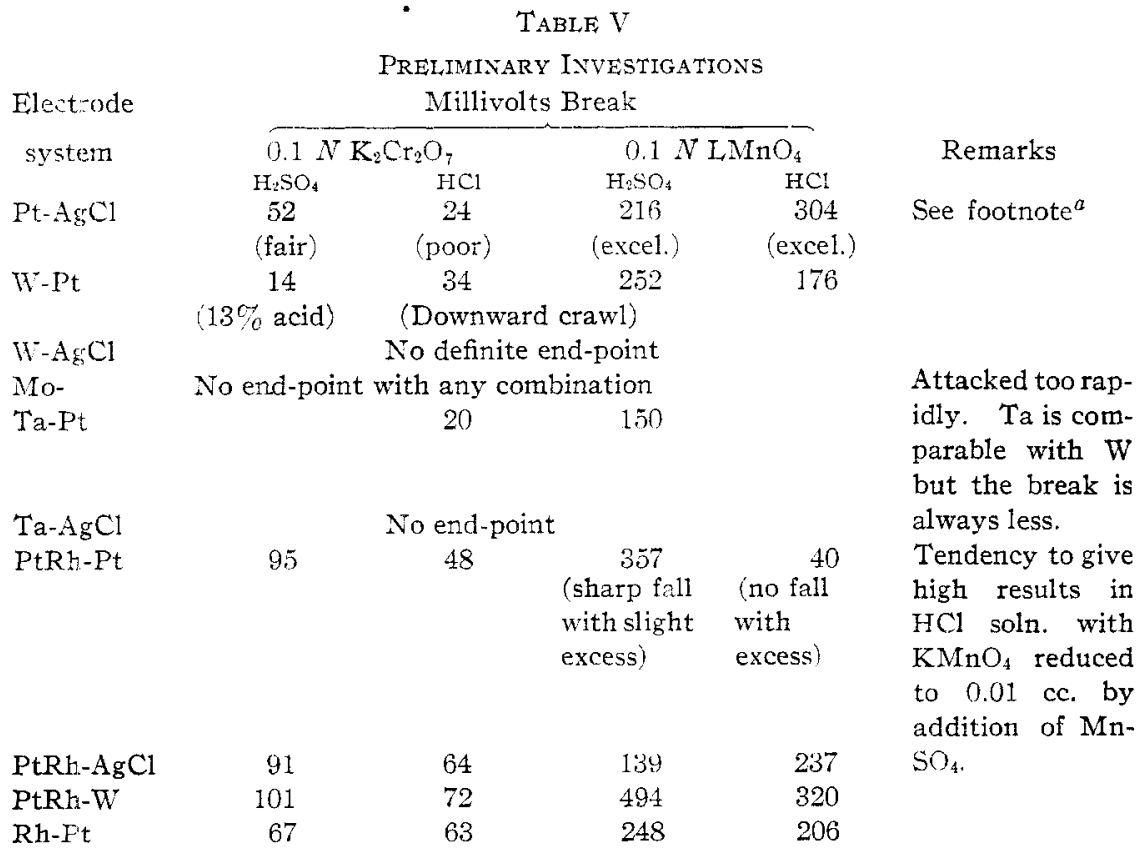




\begin{tabular}{|c|c|c|c|c|c|}
\hline \multicolumn{6}{|c|}{ TABLE V (Continued) } \\
\hline Electrode & \multicolumn{4}{|c|}{ Millivolts Break } & \multirow{4}{*}{ Remarks } \\
\hline system & \multicolumn{2}{|c|}{$0.1 \mathrm{~N} \mathrm{~K}_{2} \mathrm{Cr}_{2} \mathrm{O}_{7}$} & \multicolumn{2}{|c|}{$0.1 \mathrm{~N} \mathrm{KMnO}_{4}$} & \\
\hline & $\mathrm{H}_{2} \mathrm{SO}_{4}$ & $\mathrm{HCl}$ & $\mathrm{H}_{2} \mathrm{SO}_{4}$ & $\mathrm{HCl}$ & \\
\hline $\mathrm{Rh}-\mathrm{AgCl}$ & no e.-p. & no e.-p. & 12 & $\begin{array}{l}\text { (no sharp } \\
\text { break) }\end{array}$ & \\
\hline Rh-W & no e:-p. & no e.-p. & 110 e. - p & $\begin{array}{r}35 \\
\text { (poor) }\end{array}$ & \\
\hline PtPd-Pt & 28 & 34 & 132 & 171 & The reducing ac- \\
\hline PtPd-AgCl & 66 & 23 & $\begin{array}{c}\text { (downward } \\
\text { crawl) }\end{array}$ & $\begin{array}{c}58 \\
\text { (crawl) }\end{array}$ & $\begin{array}{l}\text { tion of } \mathrm{Pd} \text { and } \\
\mathrm{PtPd} \text { too rapid }\end{array}$ \\
\hline PtPd-W & 71 & 39 & 860 & 62 & to permit of the \\
\hline Pd-Pt & 33 & $\begin{array}{c}97 \\
(50 \% \text { acid })\end{array}$ & 208 & $\begin{array}{c}163 \\
(20 \% \text { acid })\end{array}$ & $\begin{array}{l}\text { practical use of } \\
\text { either as an elec- }\end{array}$ \\
\hline $\mathrm{Pd}-\mathrm{AgCl}$ & 64 & $\begin{array}{l}\text { no e.-p. } \\
(13 \% \text { acid })\end{array}$ & $\begin{array}{c}14 \tilde{5} \\
(13 \% \text { acid })\end{array}$ & no e.-p. & trode. \\
\hline Pd-W & 35 & $\begin{array}{l}\text { no e.-p. } \\
\text { (attacked) }\end{array}$ & 98 & $\begin{array}{c}\text { no e.-p. } \\
\text { (attacked) }\end{array}$ & \\
\hline PtIr-Pt & 70 & 75 & $\begin{array}{r}110 \\
\text { (fall with } \\
\text { excess) }\end{array}$ & $\begin{array}{l}\quad 56 \\
\text { (fall with } \\
\text { excess) }\end{array}$ & Alloy $10.5 \%$ Ir. \\
\hline PtIr-AgCl & 34 & 60 & $\begin{array}{c}100 \\
\text { (large rise } \\
\text { with excess) }\end{array}$ & $\begin{array}{l}162 \\
\text { (large rise } \\
\text { with excess) }\end{array}$ & See footnote $b$ \\
\hline PtIr-W & 25 & 65 & $\begin{array}{l}150 \\
\text { (large rise } \\
\text { with excess) }\end{array}$ & 150 & \\
\hline Ir-Pt & $\begin{array}{l}\text { low } \\
\text { (sensitive) }\end{array}$ & 33 & $\begin{array}{l}\quad 312 \\
\text { (fall with } \\
\text { excess) }\end{array}$ & $\begin{array}{l}\quad 130 \\
\text { (fall with } \\
\text { excess) }\end{array}$ & \\
\hline Ir $-\mathrm{AgCl}$ & 68 & 54 & $\begin{array}{c}55 \\
\text { (large rise } \\
\text { with excess) }\end{array}$ & $\begin{array}{c}72 \\
\text { (large rise } \\
\text { with excess) }\end{array}$ & \\
\hline $\operatorname{Ir}-W$ & 28 & 43 & 207 & 323 & \\
\hline PtOs-Pt & 50 & 33 & $\begin{array}{l}\quad 157 \\
\text { (fall with } \\
\text { excess) }\end{array}$ & $\begin{array}{l}\quad 205 \\
\text { (fall with } \\
\text { excess) }\end{array}$ & \\
\hline PtOs-AgCl & 70 & 69 & 372 & 287 & \\
\hline PtOs-W & 40 & 59 & 380 & 177 & \\
\hline IrOs-Pt & & 15 & 400 & 150 & The natural irid- \\
\hline IrOs-Ir & 22 & 52 & 309 & 242 & osmium alloy \\
\hline PtAu-Pt & 35 & 26 & $\begin{array}{l}\quad 86 \\
\text { (fall with } \\
\text { excess) }\end{array}$ & 225 & \\
\hline PtAu- $\mathrm{AgCl}$ & 57 & 26 & 185 & 59 & \\
\hline$P t A u-W$ & 30 & 36 & 280 & 65 & \\
\hline$P t-P t$ & & & $150^{\circ}$ & & Feb. 13,1920 \\
\hline $\mathrm{Pt}-\mathrm{Pt}$ & no e.-p. & no. e.-p. & not $>5$ & & Feb. 14,1920 \\
\hline
\end{tabular}

a The magnitude of the break in $\mathrm{HCl}$ solution with $\mathrm{K}_{2} \mathrm{Cr}_{2} \mathrm{O}_{7}$ is materially influenced by the condition of the $\mathrm{Pt}$ and the acidity of the solution. A freshly ignited electrode gives the best results and inçreased acidity makes the break both sharper and greater. 


\section{Characteristics of Bimetallic Systems}

The actual magnitude of the end-point break is usually less than when a constant half-cell is used with only one metal electrode. However, in the latter case, even under the most favorable circumstances, the break with dichromate little more than equals the total rise from the beginning of the titration to the end-point and it is often much less. With 2 metal electrodes the initial voltage, with zero quantity of the higher stage of oxidation present, varies considerably according to the pre-treatment of the electrodes and the condition of the solution as to concentration, acidity, and foreign salts. Upon the addition of the oxidizing agent the voltage falls rapidly to practically zero and remains at this value until the titration is within $0.2-0.3 \mathrm{cc}$. of the end-point. A slight rise then gives warning of the approaching end-point which occurs with greater sharpness than with the ustal electrode combination. The total rise throughout the entire course of the titration is so entirely negligible as compared with the abrupt change at the end-point that this latter is unmistakable. With bimetallic combinations in which tungsten forms one electrode there is a slow, continuous rise throughout the course of the titration comparable to the rise with monometallic systems but rarely amounting to 50 millivolts prior to the end-point.

The conditions in the presence of an excess of the oxidizing agent are interesting. Fig. 3 shows a slight fall in voltage in excess of potassium dichromate with Pt-PtRh electrodes. This fall is not always found under similar circumstances; sometimes the voltage remains constant after the break or, at most, there may be a very slight rise. With permanganate titrations in sulfuric acid the behavior is much more marked (Fig. 5). $0.02 \mathrm{cc}$. in excess is sufficient to cause a fall in voltage which may equal more than $3 / 4$ the total rise at the end-point. Continued addition of permanganate causes a still further decrease but with lessening velocity as the potential approaches its former zero value. This behavior with Above $50 \% \mathrm{HCl}$ the results obtained are low. Increased concentration of Fe causes a decrease in the break.

Theoretical results are obtained by titrating with $\mathrm{KMnO}_{4}$ in $\mathrm{H}_{2} \mathrm{SO}_{4}$ solution. In $\pm \mathrm{ICl}$ the tendency is to run high, usually $0.05-0.12 \mathrm{cc}$. Later titrations with concentrations of $\mathrm{Fe}$ to $2.64 \mathrm{~g}$. seemed to show this error independent of the concentration of both $\mathrm{Fe}$ and $\mathrm{HCl}$, provided the latter is not above $50 \%$. The addition of $5 \mathrm{~g}$. of $\mathrm{MnSO}_{4}$ reduced this error to $0.05 \mathrm{cc}$.

${ }^{b} \mathrm{KMnO}_{4}$ titrations with both Ir and PtIr against $\mathrm{AgCl}$ seemed to be chatacterized by a very large break with one drop excess. The break at the end-point is sharp and the larger break immediately following is sometimes 4 times the value of the smaller. The primary break was demonstrated to be the real end-point by comparative titrations with other systems.

'Idcntical electrodes cut from foil and sealed in glass. Apparently a strained condition existed in the freshly sealed-in electrodes which caused the break. Successive tirration dissipated this strain, an indication that the cud-point with bimetallic swems is a polarization phenomenon. 
excess of the oxidizing agent may be a disadvantage. When titrations are being carried out in colored solutions which veil the visual end-point, if the operator has approached the end-point so rapidly as not to observe the slight rise preceding it, he may overstep it and be unaware of the fact for some time. In hydrochloric acid solutions the break is not nearly as good as in sulfuric, sometimes only a tenth of the magnitude of the latter, but it is sharp. The fall in excess is not as marked as in the latter case and may not occur at all. It must be pointed out that the phenomenal fall applies only in the case of bimetallic systems of metals and alloys of the platinum group. Combinations including tungsten never behave thus, although the potential may "crawl" somewhat here.

\section{Analysis of the End-point Phenomenon}

Bancrof $t^{6}$ long ago pointed out that the e.m.f. of oxidation cells is an additive property and the potential of a single cell the difference between 2 single electrode potentials. The attempt was therefore made to show

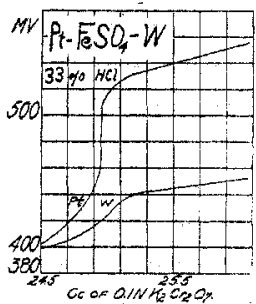

Fig. 8. the part played by each electrode in bimetallic systems. For this purpose the 2 metal electrodes and a standard silver chloride half-cell were immersed in the solution to be titrated and connected in the circuit through a small set of mercury switches in such a way that the potential of any one of the 3 possible electrode combinations was readily obtained at any stage of the titration. It is obvious that the difference between the potential of the combinations Metal 1-AgCl and Metal 2- $\mathrm{AgCl}$ must equal that of the system Metal 1-Metal 2 and, therefore, is a check on the accuracy of the latter measurement. Fig. 8 gives the single electrode potential curves of platinum solution and tungsten solution.

Fig. 9 shows the corresponding curves for platinumplatinum-rhodium under the same conditions.

The last two figures illistrate very clearly the functions of the individual electrodes. Initially, with only ferrous iron present, the relation of the 2 metals to the solution is different, resulting in an appreciable potential difference. Addition of the oxidizing agent decreases this difference which now falls rapidly to zero. As the endpoint is approached the electrodes again begin to function differently and just as the last trace of ferrous ion disappears there is a sharp change in the relative electrode



Fig. 9. conditions. It may be mentioned here that the electrodes do not always behave the same from one titration to another. The break is always present and does not alter in location but its magnitude varies considerably. Sometimes one metal may be the positive electrode, sometimes

${ }^{6}$ Bancroft, $Z$. physik. Chem., 10, 387 (1892). 
the other, .depending largely upon their pre-treatment. The electrodes used in the titration represented by Fig. 8 had been freshly treated with boiling chromic acid. After such treatment platinum is normally positive to the alloy, but the difference decreases with successive titrations and conditions may often reverse. With tungsten there is never a reversal of polarity. The platinum metals and their mutual alloys are invariably positive to tungsten when equilibrium has been established although the magnitude of the break at the end-point alters very appreciably.

The conditions in the case of the permanganate titration of ferrous sulfate with platinum-platinum-rhodium electrodes in sulfuric acid solution are given in Fig. 10.

The break with the platinum-rhodium electrode occurs in slightly greater concentration of permanganate than with the platinum. This is the explanation of the phenomenal fall discussed in connection with Fig. 5 . There can be no decrease in voltage on passing from a reducing to an oxidizing solution but there can be, and is, a change in the relative rate of increase of the single electrode potentials. At the beginning of the titration with no ferric iron present the $\geq$ electrodes function differently and a potential difference exists. This difference falls to zero in the presence of ferric ion. At the end-point, with zero quantity of the unreduced permanganate present, the potential difference

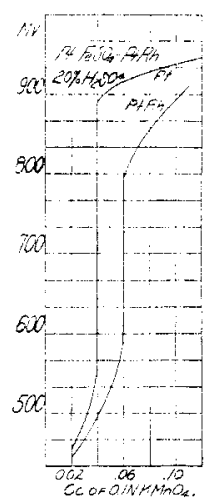

Fig. 10. reappears, to disappear again in the presence of permanganate ion. The end-point potential with bimetallic electrode systems is, therefore, not an oxidation potential in the same sense of the term as with electrode systems comprising a constant half-cell.

\section{Summary}

The constant half-cell of the usual electrometric titration apparatus may be replaced by a metal or certain alloys of the platinum group, other than pure platinum or pure palladium, and by tungsten. The end-point obtained with such a bimetallic system differs in character from that given by a monometallic, but is unchanged in location. The proposed electrode arrangement has the advantage of being essentially simpler than the usual system with a gain in distinctness of the end-point obtained.

This work was assisted by a grant from the Cyrus Warren Research Fund, for which the authors wish to express their thanks.

ANN ARBOR, MichigAN 